


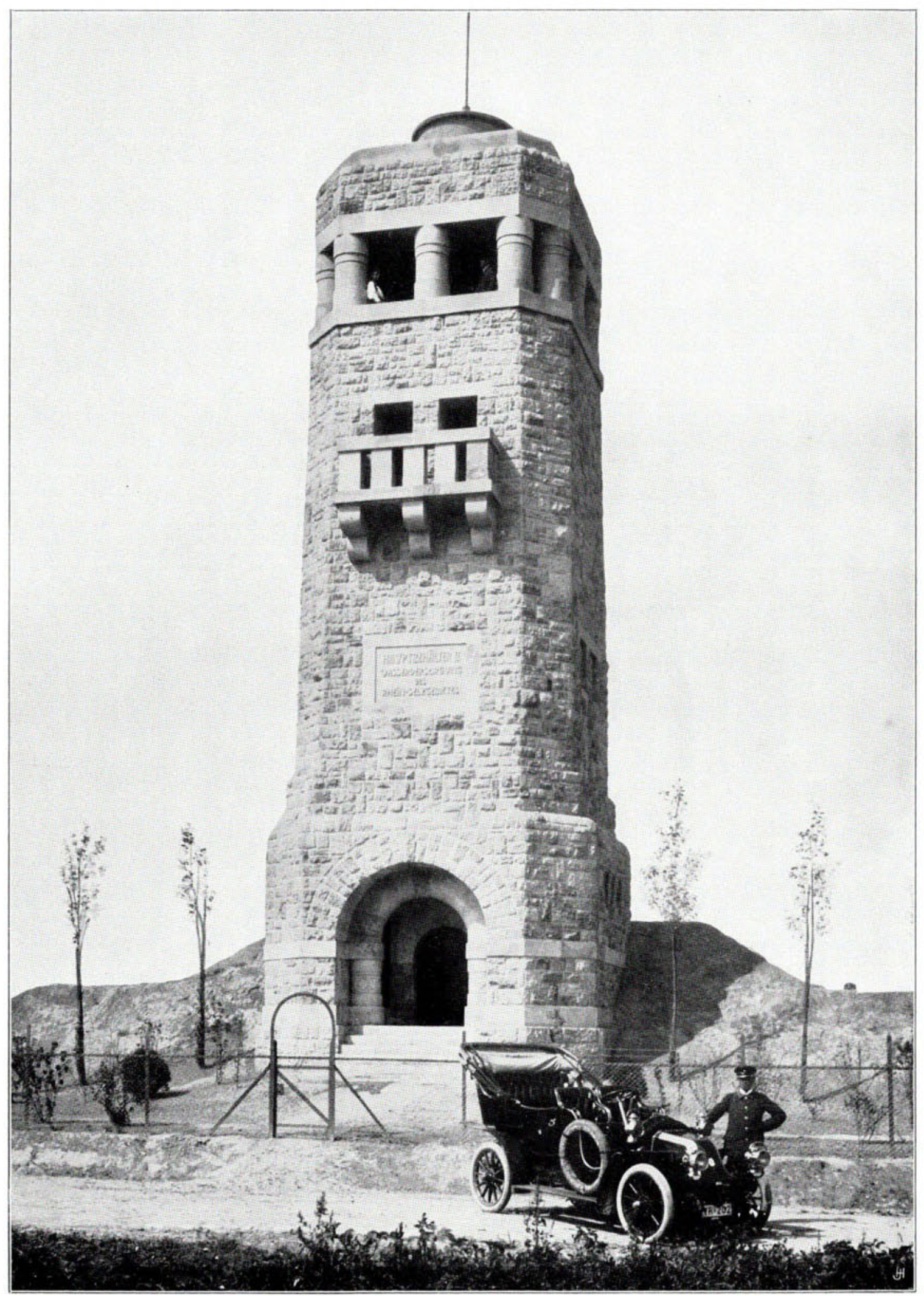

Fig. 10. Haupthochbehälter II bei Wintersheim. 


\section{DIE WASSERVERSORGUNG}

des

\section{Rhein-Selz-Gebietes}

Von

\section{B. v. Boehmer}

Großherzoglicher Baurat und Vorstand der Großherzoglichen

Kulturinspektion Mainz

Mit 10 Tafeln und 26 Abbildungen

Photographische Aufnahmen von Hofphotograph METZ-Main Z

Tafeln gezeichnet von Geometer $\mathrm{H} \ddot{\mathrm{ARING}}$

München

Druck von R. Oldenbourg

1907 
